custody of the port organization are the loads broken down and the packages handled separately. Even that is not always necessary, however, for at isolated places the practice has already begun for dock-owned pallets to go to consignee for unloading.

\title{
FutURE TRENDS
}

It is true to say, of course, that the mechanized methods described are so far being fully employed only at certain pioneer berths. Nevertheless, the modern trend is now clear. For piece goods, it is unit-load handling instead of individual package handling - to effect savings in time, space, money, and arduous labour. The evolution of this method is already far enough advanced to affect not only the types of port equipment required and the layout of quays, sheds, and warehouses but also, in the general industrial world, goods-packaging, transport-vehicle design, and the pattern of factory and other premises. There is little doubt that it will ultimately affect ship construction.

In maritime countries, speed of ship discharging and loading, with care of cargo and safety of personnel, is essential to the national economy and, although existing kinds of equipment are being improved daily, it is from the new-type appliances that the more dramatic benefits are expected. When these accrue, the recipients will not only be the port employers and the shipping companies, they will include manufacturers, shippers, receivers, haulage and lighterage contractors, many groups of work-people and, it is hoped, the consumer.

The Paper, which was received on the 18 th October, 1955, is accompanied by eight photographs and one drawing from which the half-tone page plates and the Figure in the text have been prepared.

\section{Discussion}

Mr J. H. Jellett (Docks Engineer, Southampton, British Transport Commission) said that he had been encouraged to hear Mr Lees advocate close co-operation between shipbuilder and port-owning authority in the planning stage of design of new ships. $\mathrm{He}_{\theta}$ thought he could say that certainly so far as Mr Lees's own company was concerned-who happened to be Southampton's biggest customers-there was very close co-operation in all planning arrangements, both ship and shore. But he did not think that the same held good for all Mr Lees's colleagues in other shipping lines in Britain and overseas. An extreme case was the United States when she came to Southampton on her maiden voyage and there had been the problem of unloading the baggage. The range of the problem was wide because it involved taking baggage off decks 30 and $35 \mathrm{ft}$ above the quay level and taking personnel out of decks 6 or $7 \mathrm{ft}$ below quay level. A number of inventions and unusual appliances were devised to cope with the problem.

Turning to Mr Matheson's Paper, he wished to make a few comments on the age-old problem of columns. Mr Matheson had stated that he felt that a 30-ft spacing should be adequate for all purposes and suggested on p. 253 that there was perhaps a tendency for engineers to exhibit advances in technical skill. The tomptation for the engineer to seize such an opportunity was undoubtedly very great. At Southampton there had recently been completed a two-storey transit shed in which the column spacing had been opened out to $54 \mathrm{ft} \times 49 \mathrm{ft}$. Since the calculated loading on the upper floor was $3 \mathrm{cwt} / \mathrm{sq}$. $\mathrm{ft}$, the supporting structure of the upper floor was very massive. The load down some of the internal columns was as much as 800 to 820 tons. Many people might say that the 
engineers had been extravagant, but they had offered the problem to the management very clearly, opening the spacing of the columns out gradually from a basic economic spacing of about $22 \mathrm{ft} 6 \mathrm{in}$. in both directions stage by stage, with the appropriate additional cost at each stage; when the figure finally approved was reached, that was then selected. The management had been told what the additional cost of such an exhibition of technical competence would be. The building had been greatly admired from the operating point of view because of the marked lack of obstruction from columns on both floors. The total floor area of the two floors was about 170,000 sq. ft; since the building had been opened six ships of Mr Lees's line had been accepted, i.e., one ship per week, and an average of nearly 9,000 measurement tons of cargo had been unloaded per week.

Another point mentioned by Mr Matheson was that the slope of the floor should not exceed 1 in 100. It had always been the practice at Southampton to slope the shed floors up from quay level on the waterside to the standard rail platform level at the other side of the width of the shed. That meant that there was a rise of about $3 \mathrm{ft} 6 \mathrm{in}$. to be achieved in a width which might be as little as $120 \mathrm{ft}$ or perhaps even narrower, so that the steepest floor was 1 in 28 . He realized that that did throw a considerable load on the batteryoperated trucks which carried most of the cargo moved on the floors of those sheds, but so far as he was aware that had never resulted in trucks going out of action before a shift was over.

Finally, he felt that an economic case had not yet been made out for shed doorways sufficiently high to take mobile cranes with their jibs hoisted. A crane was a lifting device, and it should not be made to function much as a moving device. It was not the structural design of the doorway that caused trouble, but the subsequent maintenance of the very large and unwieldy doors necessary to close the openings.

Mr P. R. Robinson (Messrs Rendel, Palmer \& Tritton, Consulting Engineers) said that he wished to speak on the layout of transit areas, particularly from the point of view of imports, because very often they chiefly affected the amount of transit area to be provided.

Such areas, whether whole sheds, floors of sheds, or open dumps, should be used for transit purposes only. In some ports there had been a considerable tendency during the past 10 years for goods to remain in transit sheds and dumps far too long, and some port authorities had found it difficult to insist on prompt removal by importers. Generally speaking, there should be no need for imported goods to remain in transit areas more than 5 days, but under present circumstances perhaps 10 days should be allowed.

The transit area should thus be able to accommodate the volume of goods unloaded from a ship in that time if they were cleared at the same rate as they were unloaded. Taking an average of the figures given by Mr Matheson of from 120 tons to more than 300 tons of cargo per foot of berth per annum and allowing 250 working days a year for a 600 -ft berth, one got a figure of, say, 600 tons per ship per day. Now, assuming that goods did remain 10 days in transit areas, transit accommodation would therefore have to be provided for at least 6,000 tons. Therefore, every extra day beyond the 10 days assumed of retention in transit areas increased the transit space required by $10 \%$. It was often difficult to provide sufficient conveniently arranged transit accommodation to allow for normal periods for goods in transit; it was therefore important that every effort should be made to reduce the time goods remained in transit areas to the minimum, possibly by a sliding scale of fees. An investigation by a special committee of the Liverpool Steamship Owners' Association into congestion and slow discharge had found that the over-riding cause was congestion on the quays through failure by receivers to clear goods in proper time (quoted in "The Times" of $19 \mathrm{March}, 1956$ ).

Taking Mr Lees's figure of $50 \mathrm{cu}$. ft/ton, the net volume occupied by 6,000 tons of cargo was $300,000 \mathrm{cu}$. ft. If it was stacked to an average height of $8 \mathrm{ft}$, which was perhaps high for general cargo even with pallets and certainly high for many ports abroad-especially where individual consignments were not large-the net area occupied was, say, 35,000 to 40,000 sq. ft. But since up to $40 \%$ or more of the gross area was devoted to alley-ways, lifts, and so on, the gross transit area required for 6,000 tons of cargo was actually more like 
60,000 to 70,000 sq. $\mathrm{ft}$; that did not include roads, railways, and loading platforms, nor did it allow for export cargo which might have to be stacked for loading into the same ship or the next one. Thus, the total gross transit area required for a 600 -ft berth was likely to be at least $100,000 \mathrm{sq}$. $\mathrm{ft}$. If the width of the transit area was taken as $150 \mathrm{ft}$, that area could not be provided behind a $600-\mathrm{ft}$ berth using single-storey transit sheds.

He did not like the awkward shape of transit shed shown in Fig. 2, Plate 3. If, however, rail access to the apron from the standage grids at every berth was essential, some such arrangement was almost inevitable, unless a very short multi-storey shed was used, because normally there was just not enough room between transit sheds to get in the rail curves of the necessary radius. He thought that rail access from the rear at each berth was unnecessary, and it was usually quite sufficient to have turn-outs at every third or even fourth berth. The rail movements on the running line on the apron in such cases would not need to be so frequent as to interfere much with goods passing between ship and transit shed on adjacent berths.

There were at least two other reasons why the cut-off corner of the transit sheds was objectionable. The triangular section of a shed was awkward to manage for stacking purposes, and that end could not be used for road clearance or at least only with difficulty. Usually it was a mistake to try to handle goods to and from the transit shed by road vehicles at places where railway lines existed; that applied whether the rail track was a running or a standing line. There were, of course, many cases where it had been done or attempted, but most of such layouts had been built before road handling assumed its present proportions. In a modern layout there was usually no need for such an arrangement; road and rail handling could be kept separate, although sometimes one was apt to wonder if those responsible for goods handling in ports were not subconsciously perhaps reluctant to believe that handling by road might require different arrangements from handling by rail. Railway lines for shed working must be at or towards the rear of the shed, but road vehicles could work equally well at platforms at both ends of sheds. For single-storey sheds such an arrangement was now almost essential, at least where any large proportion of the goods was still handled by rail. For multi-storey sheds the preferable arrangement was to provide for handling goods cleared by road from the ground floor from platforms at the ends of the shed, and from upper floors from the outside of an island platform at the rear of the shed; and to provide for handling all railed goods at one (or two) tracks between the island platform and the shed floor, railed goods from the ground floor being loaded on the shed side of the tracks, and from the upper floors on the island platform side of the tracks. That arrangement allowed both road and rail handling to proceed independently, as mentioned by Mr Matheson.

Finally, there were one or two detail points which he wished to mention:-

(1) The width of quay of $65 \mathrm{ft}$ noted by $\mathrm{Mr}$ Matheson was good, but $75 \mathrm{ft}$ was better.

(2) The slope of the floor of I in 100 mentioned by Mr Matheson meant that with a shed $150 \mathrm{ft}$ wide there was a difference in level between the rail tracks at the rear of the shed and on the quay, and that the rear tracks would probably be depressed below the general road level. Either of those conditions was very inconvenient; he asked the Authors whether the slope of 1 in 100 was decided upon by the fork-lift truck manufacturers' requirements or not. A slope of $l$ in 50 enabled a much better loading arrangement to be got.

(3) It was arguable whether continuous sliding doors were really an advantage. They were neither so secure nor so weatherproof as a series of fixed doors, and they did not give any more stacking space.

(4) On the question of design of ships, he asked Mr Lees whether it was possible to increase the size of hatches in view of his comments about makeshift arrangements used in ships' holds.

In that connexion, and indeed on the general question of cargo handling, he said a considerable amount of work had been done by the International Cargo Handling Co-ordination Association, but British representation so far had been rather lacking in that organization. 
Lt-Gol. R. H. Edwards (Civil Engineer, South Wales Docks), said that Mr Lees referred presumably to a Liberty ship, of which there were still a great number trading, but since they would soon reach the end of their economic life, some other type of ship would be needed to replace them. Would $\mathrm{Mr}$ Lees express an opinion as to what he thought. the cargo ship of 10 to 15 years hence would be like? Was not the naval architect's problem one of gaining maximum bulk with the minimum weight? Oil tankers and ore carriers had their machinery aft; could not that arrangement be adopted for general cargo liners? It would give an unrestricted area throughout the length of the ship for cargo spaces and hatches, and he felt should facilitate work at the ports and speed up the turn-round of the ship.

Mr Matheson's Paper was of particular interest to those who were called upon to prepare schemes for modernization of the older ports to meet present-day needs of commerce and, in his own case, the change from coal exports to general cargo.

There could be no hard-and-fast rules as to what one should do, because each situation required an individual appreciation and careful consideration to meet the requirements of the shippers and to suit the site available for development. The Author made particular reference to road traffic, which was causing much concern at certain ports, for that transport had descended upon many of the older docks, originally laid out for rail service. Road traffic had to use many ports ill provided with good road aocess, and something should be done about it. That was the concern not only of the dock authority but of the local councils, since any road improvement schemes should take into account the road approaches to and from the port, which were the responsibility of the council. Close co-operation was vital.

Congestion around quays and sheds by road vehicles was well known, but did not oceur with rail traffio because there was proper provision for dealing with it. Why should not provision be made also for road vehicles? For rail wagons there were reception and regulating sidings, so why not vehicle parks en route to the sheds for road vehicles? Such parks could hold the vehicles until called forward by telephone or some such control, thus avoiding congestion around the sheds and blocking of the roads.

Much could be done to improve congestion by the shippers in spreading the arrival of export goods to make a more even delivery to shed or ship, during the time the latter was loading.

A debatable problem was whether shed floors should be at quay level or at rail-platform height, and he would like to hear the Author's views on that. For export traffic it was desirable that road vehicles should be able to run into the shed from the roadside.

The Author recommended that doors should be continuous along the face of the shed, but with that he could not agree. He considered that alternate door openings and solid wall were preferable, if only to save maintenance of the doors, which could be slid behind the walls for safety. Timber doors were preferable and rolling shutters should be avoided, because they were very vulnerable and costly to maintain.

On the subject of quayside cranes, in the United Kingdom crane makers influenced port design, for their general practice for many years had been to design cranes on tracks of, say, 13-ft 6 in. to 20 -ft gauge. The cranes took up, therefore, quite a considerable amount of quay space. He wondered why the type of crane substructure common on the Continent was not more used. That type of substructure had the front legs on a single track behind the coping and the other end supported on the front wall of the shed, the crane superstructure being carried on girders joining the legs and the shed. That arrangement gave an unrestricted quay wide enough for four or five rail tracks. Would the Authors of the last two Papers express their views on that?

Mr J. T. Williams (Divisional Fngineer, Port of London Authority) wished to make a few brief remarks first on Mr Tooth's Paper, and then to raise one or two detailed points on Mr Matheson's Paper.

Mr Tooth had mentioned that the introduction of mechanical appliances had in some cases led to dramatic results; it was no exaggeration to say that the fork-lift truck and the mobile crane had caused something of a revolution. There was no doubt that one felt 
a different tempo, a different kind of rhythm altogether, when watching a fully mechanized quay in operation. He wondered why that had taken so long to come about. When studying the subject, he had referred back to a Paper by Binns ${ }^{2}$ in 1932 , in which it had been mentioned that the average working effort of a dock labourer was about $\frac{1}{10} \mathrm{~h} . \mathrm{p}$. With a normal dock labour gang, there was about 1 h.p. in operation as the unit of power. It was also mentioned in Mr Binns's Paper that the manual handling of goods was 100 times more expensive than doing it mechanically. Now there was the fork-lift truck, which could develop about 35 h.p.

He thought the reason for delay in introduction of mechanization as one saw it today was partly the high capital cost of the special plant and partly the difficulty of keeping it reasonably fully employed. That applied particularly to quay cranes and other static appliances. But mobile cranes and fork-lift trucks had changed that, because they were very versatile machines which, because of their mobility, could be kept reasonably fully employed enabling cargo to be handled more speedily, thus justifying their introduction and existence.

A very big improvement in handling of eargo should be expected when using a 35-h.p. unit instead of a 1-h.p. unit; speeds of handling had been increased by about $30 \%$, so ono was told, but he felt that the fork-lift truck would be capable of doing much better than that when the other links in the chain, such as the design of ships and sheds, had also been improved. He thought therefore that Mr Lees's opinion, that a fundamental change in the design of the ships was unlikely, was disappointing.

Mobile cranes and fork-lift trucks might be expected to require in proportion more maintenance and quicker replacement than other items of dock plant. Bearing that in mind, he thought the overall economic picture should be considered. Could $\mathrm{Mr}$ Tooth give some further indication of the economic aspects of the mechanization which he had described so vividly? Were those benefits about which $\mathrm{Mr}$ Tooth had spoken, important as they were, limited to the quicker turn-round of ships and the greater use of shed space? At the end of the Paper, Mr Tooth hoped piously that some of the benefits would be passed on to the consumer. Was there any real hope of that?

Mr Tooth had emphasized that, because of the introduction of mechanical tools, berths should be constructed on a new pattern, and Mr Matheson had also stressed that space should be left for accommodation of mobile plant, pallets, and so on. He suggested that it might be advantageous to provide about $20 \mathrm{ft}$ between the rear of a shed and the nearest rail track. That space could then be used for stacking pallets and other gear, and for operating mobile cranes, whilst leaving both rail tracks and roadway clear. He thought also that, in view of the cost of construction of loading banks, unless the ground levels were particularly favourable, loading banks should, if possible, be dispensed with.

On p. 251, Mr Matheson stated that "Consistent with fulfilling its proper functions as a safe coverage for goods, a transit shed should be of the lightest and cheapest type possible without incurring heavy and constant expenditure on maintenance." Goods had to be protected from the elements and he thought that one of the elements which the dock engineer was very conscious of was fire. What sort of fire grading of buildings would $\mathrm{Mr}$ Matheson recommend? In the case of a multi-storage shed with upper floors used for warehousing, the fire load, even for contents of average calorific value, would be considerable, and consideration would have to be given to constructing fire walls to divide the shed walls into suitably sized compartments. That might limit the use of fork-lift trucks, because the maximum size of doorway permissible in a fire wall did not allow the passage of such machines. In some cases verandas could be used for access between compartments, but that might not always be convenient or possible. There was a case for investigating the possibility of allowing larger fire doors by the carrying out of suitable full-scale fire tests.

Mr Matheson had suggested that the use of structural steel in two-storey sheds might be an advantage. To what extent did Mr Matheson consider that the steelwork should be

1 Asa Binns, "Recent Developments in the Mechanical Equipment of the Port of London Authority." Proc. Instn Mech. Engrs, vol. 122, p. 575 (May 1932). 
protected from the fire protection point of view; when should sprinkler systems or dry rising mains be used; or a warehouse given full protection by the adequate covering of all steelwork ? Some fairly recent dock fires had given prominence to that problem.

There was one last point on which he hoped that Mr Tooth might be able to give a little more information. In a recent article in the press, a shipping concern had said that before the second world war their ships completed three voyages a year and that 5 years ago those had been reduced to 2.25 and in 1955 to only 1.9. To what extent, he wondered, was that because cargo ships were getting larger and possibly were loaded deeper, both inwards and outwards, and therefore tended to spend more time in port?

Mr F. D. M. Gamble (Chief Mechanical Engineer, Samuel Williams \& Sons Limited) said that he had been surprised to find how many similar problems there were in the large organization which Mr Shire represented and the smaller organization at Dagenham Dock. He would like to swop experiences with Mr Shire on many points raised in the Paper, but proposed to confine himself to one aspect of grabbing cranes which might be of general interest.

At Dagenham Dock there was very high emphasis on bulk discharge and considerable enthusiasm for the improvement of both equipment and methods of operation. In 1938 delivery was taken of three grabbing cranes of $7 \frac{1}{2}$ tons capacity and $70 \mathrm{ft}$ radius. They were equipped with 150-h.p. hoist motors and had a hoisting speed of $200 \mathrm{ft} / \mathrm{min}$. 'Those cranes had been regarded as highly satisfactory at the time, being better than anything previously used in the dock, and were still giving yooman service. However, since after the war there had been a demand for additional cranes, it was felt that advantage should be taken of experience during the war years. Many innovations were embodied in what was virtually a standard crane, and the first post-war machine was delivered in 1948. It had a 200-h.p. motor and a hoisting speed of $250 \mathrm{ft} / \mathrm{min}$.

When the crane was put into operation, it had been with some embarrassment and disappointment that they had found very little increase in rate of discharge despite the higher hoisting speed. It was found that money had been spent on a bigger motor and higher torque, but that unfortunately a lot of inertia had been bought as well. The new crane accelerated more slowly than the old machines.

Fortunately there had been an opportunity for them to recover their self-esteem. They were just starting to use at Dagenham a crane of about the same capacity of $7 \frac{1}{2}$ tons, and in the design stage had put great emphasis on the reduction of inertia. That crane was arranged to give a hoisting speed of $400 \mathrm{ft} / \mathrm{min}$.

Fig. 37 showed a comparison between the accelerating speeds. The immediate post-war crane actually took longer than the pre-war crane up to $21 \mathrm{ft}$, where the two cranes had the same hoisting time. After that, the more powerful crane started to make its way. The new crane just being put into service accelerated by comparison at an enormous speed and went on hoisting at $400 \mathrm{ft} / \mathrm{min}$. A 2l-ft hoist, that took $7 \frac{1}{2}$ sec for both the older designs, was accomplished in approximately 4 sec with the new crane-a substantial improvement. The graph, however, was not entirely realistic, since it assumed that a full grab was lifted from rest, whereas in practice the hoisting motor gathered momentum during the process of closing the grab.

The now crane had other interesting foatures. In the control cab the driver sat with a glass panel beneath his feet and he had miniature joystick controllers for the hoist and the combined slew and luff. The cabin was symmetrical with the jib, the jib being bifurcated or straddling the cab. The driver had an excellent view on both sides and underneath. Also in the cab was a recording/weighing machine which had been developed about 7 years ago at Dagenham, and was he beliered still the only machine of that type which was automatic. It needed no weighman and it added up the net weights of each grab-full and recorded them on a paper strip.

In addition to making the cycle of grabbing quicker, it was equally important to lift up as much material as possible with each cycle; that depended upon grab design. A port owner spent many hundreds of thousands of pounds on quays, jetties, and ancillary services, but the whole turn-round of ships at a bulk-discharge port depended on the 
output of the grabs which, by comparison, were cheap items, the price being less than

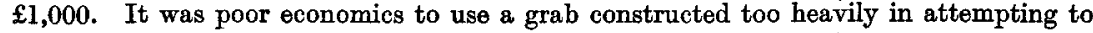
save money on grab repairs, or to use a grab which was designed for material having

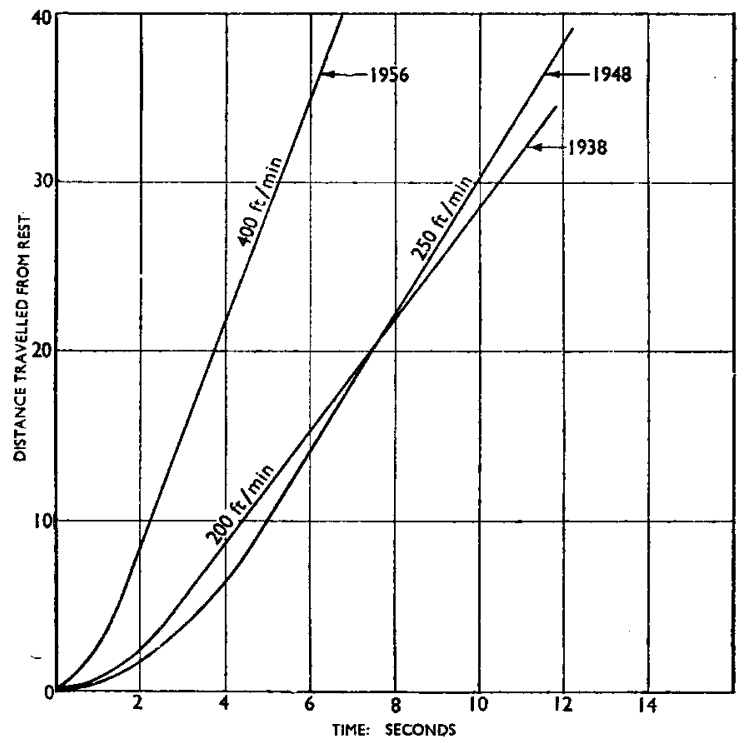

Fra. 37

different characteristics or different density. For that reason, he was interested in $\mathrm{Mr}$ Shire's remarks with regard to the all-aluminium grab, and he hoped that when it came into use Mr Shire would make the information available.

Mr N. N. B. Ordman (Divisional Engineer (Civil), Port of London Authority) said that his remarks were confined to the Papers by Mr Tooth and Mr Matheson. The variables underlying problems of cargo handling were very numerous, so that an analysis of all the factors concerned was rather intractable. Mr Matheson stated at the beginning of his Paper that anything in the nature of a general specification could not be drawn up; that must be accepted. But he was not convinced that the variables were so numerous and so dissimilar that they were not susceptible to some degree of rational analysis to a greater degree than was normally attempted.

The sort of thing he had in mind was a correlation between the size of ship, the type of cargo, and the size of transit shed required to give the optimum and most economic service. Such a correlation should be based on the analysis of a very large number of ships and a large number of different types of cargo during many years.

An investigation of that kind had been done and the results recently published in connexion with the design of a general-cargo berth at the Port of New York. Indeed, it was the type of study that must precede the design of any new port. He thought, however, that it should also be carried out as routine at British ports to establish trends and to produce data on which to base developments.

The length of the transit shed was normally determined in relation to the length of the ships using the berth, but with the conception of continuous roofing over the full length of a multi-berth quay a greater degree of flexibility was available in that dimension; 
with the development of mechanical-handling equipment the trucking distance was no longer such a rigid criterion, and that gave greater flexibility in the width of the shed. With greater flexibility in those two dimensions, the area of the shed was no longer so closely determined, and it became necessary, therefore, to evaluate other criteria.

If more data were available it might be found that there was a tendency for the area now provided to be rather less than the optimum, and, with the restrictions on the area available for dock development in the United Kingdom, he thought that forced them to give more attention to multi-storey sheds.

With multi-storey sheds the problems of cargo handling became more involved. On the quayside the difficulty was not so great, because where there were quay cranes they could without difficulty, as Mr Matheson had indicated, land goods out of ships on to the upper floors. On the land side, however, the problems of delivery to road and rail and from road and rail were more difficult. To meet that problem reliance must be placed on the ingenuity of those who designed mechanical-handling tools.

Mr Matheson had given some factors of the cost of multi-storey and single-storey transit sheds; those figures agreed with others which he himself had obtained, but they did not take into account the cost of extra land involved in a single-storey transit shed compared with a multi-storey transit shed with the same floor area. In many cases he thought that would be very important.

In that connexion there was a significant point in Mr Tooth's Paper; he had said that with the development of mobile handling equipment not only should ample space be provided within the transit sheds, but large open spaces should be provided outside and around those sheds for wide roads, parking areas, and offices. The provision of those large areas was often difficult and sometimes impossible, and the obvious solution was development in height. A realistic appreciation of the economy of that type of development, he felt, could not really be made until more of the research of the type he had indicated had been done to provide the data needed.

Mr R. R. Verner-Jeffreys (Assistant to Road Motor Engineer, British Railways, Western Region, Slough) said that he would confine his observations to Mr Shire's Paper, because it dealt with the subject with which he was more closely associated.

Mr Shire had referred to economy in operation of cranes with diesel instead of petrol engines. In the undertaking with which he was associated, a number of mobile lifting appliances, mobile cranes, and fork-lift trucks, had been converted from petrol to diesel. They had found that fuel consumption with the diesel engine was approximately $\frac{1}{4}$ of that of the petrol-engined vehicle. Since diesel oil was untaxed, fuel costs would be only about $\frac{1}{8}$ with the diesel-engined appliance compared with the petrol-engined appliance.

He agreed wholeheartedly with Mr Shire's opening observations on accessibility, particularly with the fork-lift trucks, from the point of view of maintenance. It had been his experience, however, that with the diesel-engined appliance many problems previously encountered with the petrol-engined machine had been overcome, as a result of the different characteristics of the diesel engine.

Mr Shire had referred to engine overhauls. It was his experience that on diesel-engined machines the injectors did require attention every 500 hours, as Mr Shire stated, but he suggested that the removal of the cylinder head in those intervals should not be necessary if heavy-duty lubricating oils were used. He had found that it was quite normal for a machine to operate between 1,000 and 2,000 hours before it was necessary to remove the cylinder head; the removal of the cylinder head was dictated by the valve seating condition.

Reference was made in the Paper to a complete stripdown every 2,000 hours. That had not been his experience. With the use of heavy-duty lubricating oil an engine life of 5,000 to 6,000 hours could be expected. To obtain that life, he agreed, it was very important to ensure that engines had efficient thermostats to keep the cooling water at a reasonable temperature.

On p. 275 costs of various repair items were, he thought, a little high. He thought that for regrinding an average-size diesel-engine crankshaft $786 d$ per pin was nearer the mark.

On p. 257 there was a reference to metallio tires. His undertaking had used those tires 
in recent years on mobile cranes and found them very satisfactory. On cranes with the castor wheel at the rear the $90^{\circ}$.lock could still be obtained despite the tire being pneumatic, whereas with the normal conventional pneumatic tire it was necessary to restrict the lock, in the case of the appliances he was thinking of, to $64^{\circ}$, which was a severe operational embarrassment. How had Mr Shire ensured that the pneumatic tires were kept at the correct pressure? He presumed that was done daily.

Lastly, in regard to the reference to up-turned exhaust pipes on p. 257-- to which $\mathrm{Mr}$ Tooth had also referred - he had encountered difficulties with that also. When fork-lift trucks were working in confined spaces, as in warehouses, up-turned exhaust pipes had been fitted to keep exhaust fumes away from the driver. On the other hand, on some of the heavy-duty fork-lift trucks with up-turned exhaust pipes working in open yards it had been found that the exhaust gases got nearer to the driver than when the pipes were left below in the conventional position. He thought that the position of the exhaust pipes was very important but required more research to find the best position for them.

Mr R. F. McBride (Mersey Docks and Harbour Board) said that he was particularly interested in Mr Shire's Paper. It was part of his duty to maintain diesel and mechanical appliances. In Liverpool there was a similar problem to that mentioned by the previous speaker and it had also been his experience that diesel engines went $5,000,6,000$, or 7,000 hours quite commonly without a major overhaul.

Mr Shire had mentioned tubular jibs, which were now becoming quite common. There were none at Liverpool, however, and he wondered whether the Author could give some information on the ease or cheapness of repair compared with the conventional jib.

With regard to the diesel crane, he had been surprised at the period of 5 years mentioned as being necessary to recoup the $\mathfrak{1 , 2 0 0}$ cost of converting to diesel from petrol. At Liverpool they had recently converted thirteen 5-ton cranes from petrol to diesel, and they expected to get the money back in about 15 months. The figure involved was more than $\mathfrak{E} 3,000$.

A point he had not noticed in the Paper with the diesel crane was the question of a spark arrester on the exhaust pipe. He had found that most silencers as received from the makers were very inefficient with regard to spark arresting. If a crane was working in a shed containing cotton or anything inflammable, it was essential that an efficient arrester be fitted.

In the Paper, he had not noticed any record for wire-rope examinations. He assumed that they were carried out daily in the normal routine examination.

Another point that had puzzled him was whether to use anti-freeze in winter, or to insist that radiators should be drained every night. That was not often mentioned, but there must be some system of protection for the plant.

In regard to greasing or oiling of the plant, anybody with a large number of mobile machines realized that greasing and oiling was a very important but difficult job which had to be carried out regularly. Mr Shire had mentioned $35 \mathrm{~min}$ for oiling. Did that refer to one crane-or to how many cranes? At what time of the day could greasing be done? The crane could not be taken off its job, and to do it outside working hours meant overtime and high costs. At Liverpool the driver was made responsible for that operation. Each driver was, so far as possible, kept to one particular crane, and it was part of his job, before going to work in the morning, to carry out full greasing operations.

Mr Colin Hammersley (Chief Mechanical and Electrical Engineer, John Laing \& Son Ltd) said that he would confine his remarks to Mr Shire's Paper. Mr Shire made it clear in his introductory remarks that the important thing was to apply the correct machine in the correct fashion. To that he would like to add, from his own experience, that it was essential to carry with one the people who were going to use the machine, from the manager to the operator. The technical probl ms were relatively easy, but problems of ensuring that the people who were going to operate a machine were fully conversant with the benefits to be derived, and were in tune with oneself, were more frustrating.

There was reference in the Paper to tubular steel jibs. He was delighted that Mr Shire 
had emphasized that, because he did not think that nearly enough use was made of tubular structures in the United Kingdom. With welding tubular constructions could now be made in a way not previously possible. A common way of producing an elegant structure was to use tubular steel for crane jibs. There were some fine examples in existence, but unfortunately some of the largest crane manufacturers still used the old methods. Rivets were often used rather than welded joints.

In regard to saving in cost, he quoted an example of the use of tubular steel versus conventional methods which had concerned a large and well-known crane and plant manufacturer. The example was not a crane, but another type of structure. He had designed a structure making use to a large extent of tubular sections, and had submitted it to the manufacturer with a request for their price for making it. The price given had been about $90 \%$ more than the estimated cost of making it in his own firm's workshops. He had been so worried about it that he had taken it up with the manufacturers' design department and found that whereas his design required $5 \frac{1}{2}$ tons of steel, the manufacturer had estimated the use of between 12 and 14 tons. His firm had made the equipment themselves, and it had been working on sites for 3 or 4 years.

A good example of the modification of plant mentioned in the Paper was the crane for timber handling. First, there was the question whether, and if so by how much, the crane was derated for that particular duty? Possibly it was derated 25\%. Having derated it, was there any extra counterbalance required on the rear? What was the tire pressure, and also, if it had been derated, was any step taken to take advantage of that fact by putting in smaller operating motors? In other words, had the modification of that crane in the way described been justified, or would a machine purpose-made for the job have been more suitable? Of course, that question was tied up with whether the crane was required for normal purposes as well.

He noticed that an example was given of conversion of steam cranes to diesel hydraulic. Had diesel-electric operation also been considered, and, if so, was that method considered less attractive?

There was an interesting solution to a roof handling problem given near the end of the special-purpose section of the Paper, i.e., the transporter. How was the transporter moved between one flap and the next? Did a man have to climb up on the roof to reach the control, did he do it by swinging the pendant between adjacent flaps, or how was it done? If the man had to go on the roof, there might be possibilities for development of a system of push-buttons, one at each flap to control the movement of the transporter between adjacent points. Quite easily an interlock on the pendant could be provided to stop the transporter being moved by an unauthorized person from any other flap position.

Fig. 21 showed a small truck of tubular steel sections. He would like to think that the manufacturer had not given his last word, since it did not appear the most elegant design possible in that sort of truck. He presumed it was a proprietary article.

Referring to maintenance, in the organization with which he was at present connected they had found it useful to have mobile plant inspectors visiting the working areas, which admittedly were widely dispersed, to check maintenance of plant. Did Mr Shire think that would be an advantage inside a confined working area as at the docks, which were fairly close together from the point of view of supervision?

With regard to the testing of cranes and appliances, did Mr Shire's organization find it worthwhile having a set of standard test weights to carry out their own Statutory tests on lifting appliances every 12 months, or did they have that done from outside?

$\mathrm{He}$ also wished to refer to mild-steel slings and lifting tackle. The use of alloy slings was no doubt satisfactory in a confined space where the type of lifting tackle could be controlled, but there might in some cases be a danger of mild-steel units being mixed with ones in alloy steel and the heavier load thus being lifted with the mild-steel sling.

With regard to the hiring of plant, he could only quote his own experience. Mr Shire's suggestion that the operating company should hire plant out to its own users was practised fairly generally throughout the civil engineering industry. Why could it not be applied in the same way at the docks? 
Mr E. Loewy (Senior Engineer, Sir William Halcrow \& Partners, Consulting Engineers) said that he wished first to ask, in regard to Mr Lees's Paper, why greater use could not be made of side-entry loading into ships to eliminate the quayside crane which, though forming an essential link in the handling chain, was a link which made the loads move in the wrong direction. Such side-entries would enable a fork-lift truck or small lorry to run straight into the holds. He believed that certain small ships in Denmark had that provision, but why could not the practice be adopted on a wide scale for general cargo handling on ocean-going vessels ?

Turning to Mr Matheson's Paper, he was glad that, although at the outset the Author said that an idealized layout for ports could not be considered, he did proceed to show one such conception. Such things were valuable because many engineers were from time to time concerned with construction of new ports, and could not then be guided by local practice, because it did not exist. He thought that the layout in Fig. 2, Plate 3, was very interesting but it rather begged a basic question not mentioned in the Paper, namely, the relative merits of berths laid in a long line along the margin of a water area and berths in the form of fingers or jetties set out at an angle into the water area. The type of layout that the Author showed was not normally possible on a finger form of construction because the width could not usually be obtained at a reasonable cost. Such things as warehouses had to be put somewhere else. But even on the Author's own layout no provision appeared to have been made for the easy movement of goods from the ship's side or from the transit shed into the warehouses. A complicated movement seemed necessary instead of a direct transfer straight across. The system of railway lines to each berth seemed to cut across the movement he had in mind, and also seemed to interfere with the necessary end-loading of the transit sheds, which was normally the only way in which lorries could get to transit sheds satisfactorily.

That brought him to the difficult question of making provision for lorry access to transit sheds. Everywhere in the world it was necessary to face the fact that road traffic was going to increase, and yet the ordinary conventional transit shed, which might be $500 \mathrm{ft}$ long and 100 to $150 \mathrm{ft}$ wide, did not readily lend itself to lorry access except at the ends, where the volume of goods that could be handled was very much less than down the sides. Lorries could not be mancuvred easily in a direction parallel to railway wagons, and therefore the long length of the shed was normally difficult to use. That problem became more troublesome with multi-storey sheds. He would like to have the Author's views on the possibility of allowing lorries to drive into the sheds, as was sometimes done in very large sheds in France. That also tended to eliminate the need for the platform at the back of the shed, which had been commented on by other speakers.

In regard to crane jibs being zinc-sprayed or shot-blasted, he thought that the Author's comments would probably apply only to the United Kingdom. Certainly in tropical countries, with severe corrosion, galvanizing or even the use of aluminium jibs was often justified. $\mathrm{He}$ wondered why British crane manufacturers seemed so conservative in their designs. Post-war British eranes looked very much the same as those 25 years old, despite improvements on the mechanical side. However, some of the persuasive German advertising literature seemed to show a radical re-thinking of the form that a cargo crane should take.

Mr J. P. M. Pannell (Engineer to Southampton Harbour Board) said that with regard to the column spacing problem, he thought that $\mathrm{Mr}$ Tooth put the matter very cogently when he used the words "a reasonable approach".

He wished to refer mainly to Mr Shire's comments. An ultimate shape of the joystick type of control seat for cranes had had rather astonishing repercussions. It looked too much like a comfortable club chair, and certain policy-making bodies seemed to think that a club chair was not suitable for a crane driver to sit in. The final shape was to some extent a logical conclusion, and although it looked the way it did, it was a highly efficient way of using the driver's effort. He thought that ultimately that type of thing would be adopted. 
There was one rather surprising effect of the improved efficiency with which his authority was struggling at the present time. Unlike a large authority which had absolute control of its power supply, his authority had a supply from the local electricity board, and the question of diversity was coming in. With increased efficiency the diversity was getting narrower and narrower, and it was sometimes found that the breakers were coming out at quite frequent intervals.

As regards painting, there had been no mention of flame de-scaling, and he thought that some comment on it might be worthwhile.

Mr R. G. Taylor (Assistant Chief Engineer, Tubewrights Ltd) said that it had been music to his ears to hear Messrs John Laing's representative pleading for more tubular structures. His own organization had been pioneering tubular structures for many years, and he felt that even now sufficient interest had not been shown in that new development.

The repair of tubular jibs had been mentioned by the speaker from Liverpool, who had made a classic understatement in saying that they were becoming popular. They had been in use for at least 14 years. The first tubular jib had been a 30 -ft one and it was still in use although very much sub-standard by present practice. Tubular jibs were being made literally by the thousand, and were being used all over the United Kingdom by some of the most reputable crane manufacturers.

Types of jibs and what one could do with a tube were very interesting subjects. Joints on to surfaces at any angle could be made without any difficulties of fabrication. That meant that one could use the triangular jib, which was a completely self-bracing determinate structure, without any difficulty in the shop. That type of jib could be made economically in any other type of section. It could be made with rolled steel angles and gussets, but the cost of forging and building gussets or angles prevented it being economic.

As regards maintenance, assuming that the initial prices of the steel $\mathrm{jib}$ in the oldfashioned type of steel compared to tubular steel were the same, there was straightaway a very much smaller problem from the maintenance point of view. With the tube itself, there was virtually no area for deposition of dirt and corroding materials. Furthermore, throughout Britain there was happening the sort of thing which he was sure, as engineers, they would agree ought to be banned. Pieces of angle were separated with a $\frac{3}{8}$-in.-thick piece of plate; it was spliced. Not only was it filled up; with gusset, but a cover plate was put underneath. Dirt got in and could not be got out, nor could it be cleaned; if it could be cleaned, it could not be painted.

Apart from the surface area itself, it would be found that job for job the tubular material would give about a $40 \%$ or more reduction in area. Figures were quoted in $\mathrm{Mr}$ Shire's Paper for shot-blasting and painting jibs. He did not know whether the prices given for painting and shot-blasting and so on were for a tubular job, but the cost of such work was $£ 500$ for 3-ton and $£ 675$ for 5 -ton cranes. Although painting was done only once in 15 years he suggested that if the area was instead at Beckton gasworks a new crane would be needed after probably 7 to 10 years at the most. In other words, Mr Shire's figures were only comparative for one part of the country. It could not be said that jibs were to be painted once every 15 years any more than it could be said that they were to be painted every 2 years. The thing to bear in mind was that every time they were painted the less area one had to paint the more economical the job became. If $\frac{1}{3}$ the area to be painted could be saved and three coats were used, the saving was one coat of paint per job.

Not enough attention was paid to protection of cranes. Many sorts of protected steel were obtainable nowadays. Most people were aware that red lead was not the best protection, particularly in seaside districts. Why not use galvanized steel? Why not shot-blast and metal-spray the job? Why not shot-blast the whole lot? His firm had done structures of large span that could well have been storage sheds, where they had saved so much surface area that it had been an economic proposition to shot-blast and metal-spray the whole thing at no more cost that it would have cost to paint the orthodox structure. 
On the question of column spacing, it would be possible to have a completely tubularframed storage shed of 100 -ft clear span, $16 \mathrm{ft} 8 \mathrm{in}$. grid, at about $22 \mathrm{lb} / \mathrm{sq}$. $\mathrm{ft}$. If something bigger was needed, there was the 220 - $\mathrm{ft}$ span and $40-\mathrm{ft}$ grid at less than $7 \mathrm{lb} / \mathrm{sq}$. ft. A larger size was $150 \mathrm{ft} \times 140 \mathrm{ft}$ at less than $8 \mathrm{lb} / \mathrm{sq}$. $\mathrm{ft}$.

All he pleaded was that those who were at that very moment sitting on one of the revolutions that had taken place in Britain-a welded tubular support-should in their own interest try to apply the same principles to their structures both on the dockside and anywhere where steel was used.

Mr W. J. Sivewright (Assistant Engineer (Civil), Port of Bristol Authority) noted that Figs 2 and 3, Plate 3, of Mr Matheson's Paper showed alternative arrangements of cranes in relation to the front of the quay. At first sight, whatever the structural reasons for the arrangement, that shown in Fig. 2 appeared to give the driver a better view of the hold and the hatch. In fact, however, in discussing the matter with drivers he found that they preferred the arrangement shown in Fig. 3, because they did not have to peer down at such a vertical angle. Of course, the difficulty would be overcome by the insertion of a floor panel as in Samuel Williams's crane. That did bring to mind the point that in design some regard should be given to the preferences of operators, particularly because dock operators and employees were rather sensitive plants. Their preferences might not be valid, but the psychological effect undoubtedly had some bearing on efficiency of operation.

The remainder of his remarks would be confined to Mr Shire's Paper. Palletization had been very much in the forefront in the discussion. The maintenance costs quoted by $\mathrm{Mr}$ Shire appeared high. The Port of Bristol, with a holding of about 3,500 all-timber pallets, had returned to shop annually about 140. Of those, about 25 were scrapped and subsequently replaced, and the remainder were repaired at an average cost of $£ 318 s$ each. The cost of renewals and repairs together worked out at $3 s 6 d$ per annum per pallet, or $3 \%$ on the capital cost. Obviously wear and tear depended on how much the pallets were used in transport compared with their use in storage. Could $\mathrm{Mr}$ Shire relate his costs to ton-lifts or even to the number of lifts per pallet? A factor which might be involved was the number of pallets per truck. The Port of Bristol held 200 pallets per fork-lift truck.

Except in Mr Matheson's Paper, there had been little mention of dispatch from upper floors of multi-storey sheds by gravity chutes, box slides, and the like. Would not some such arrangement have obviated the expensive arrangements referred to at the bottom of p. 260 of Mr Shire's Paper? There was a case at Avonmouth where two sheds had been provided with rear roof cranes which had never been used because there were more favoured facilities for getting goods out of the shed by gravity on the roadside.

With regard to the painting of cranes, in spite of Mr Taylor's remarks he agreed with Mr Shire that, generally, expensive preliminary preparation on a new crane was scarcely justified. Care should be taken, however, when the crane was new, to watch that it was not going to handle highly corrosive goods by grab. Breakdown of painting could occur at a very early stage in such circumstances.

Mr Shire mentioned that d.c. cranes had proved satisfactory. Was one to read that as a preference for d.c. cranes against a.c.; if so, would $\mathrm{Mr}$ Shire give his views on that matter?

Finally, he felt that Mr Shire's costs of maintenance should be taken as general rather than particular. To take the case of an oiler, surely the cost of oiling on the class of plant referred to depended very much on the distribution of plant about the dock estates and the extent of the docks estates?

** Mr G. A. Wilson (Chief Engineer, Port of London Anthority) observed that the Papers gave a good account of current practice and as such would be most helpful. Mr 
Tooth, almost alone among the Authors, had speculated about the future and that was particularly praiseworthy because he knew the many difficulties encountered in the introduction of new methods. Mr Shire had also looked into the future when he anticipated that ultimately the main source of power would be electricity generated atomically.

Mr Lees was, however, conservative; he did not expect much change, but it was known from experience, sometimes rather costly, that changes in ship construction were continually taking place and Mr Wilson believed the clue lay in conclusion 10 of the report of the British National Committee of P.I.A.N.C. on the depths to be provided in seaports, which stated:-

"There is no evidence of a continuing general trend to increase the size of all types of ships. Where increases are taking place they are in respect of certain trades only. In these trades, under the influence of economic considerations, the smaller sized vessels in each class, however, tend to be replaced by vessels of greater dimensions. Such increases are determined partly by the requirements of the trades concerned and partly by existing or projected port facilities."

The idea there was that the largest and therefore probably the newest vessels in each class did not change very rapidly, but when smaller vessels in a class were replaced, new developments were always incorporated and those were the changes which were felt by Harbour Authorities.

Perhaps Mr Lees would admit that there were at least three features which Mr Wilson had noticed and which had been mentioned by other contributors which might be forerunners of more extensive development. The first was the siting of the engines aft, as in the Southern Cross. Craig had shown ${ }^{2}$ that there were many difficulties to be overcome, especially with trim, but with the reducing weight of main engines, the layout which permitted a long clear hatch might become attractive to shipowners and might make the introduction of mobile cranes mounted on a carriage on rails spanning the hatch well worthwhile. Mr Loewy had mentioned the coasting vessels using Copenhagen, which had doors in the side, the quay being equipped with a ramp which was set to meet the level of the doors. The fork-lift trucks ran up the ramp and through the doors, descended in a lift to the required deck, set their palletized cargo, and returned to the shore. Those particular coasting vessels operated on a regular time schedule and the mechanized handling of cargo was justified by the regularity which it ensured.

More determination to reduce the cost of handling goods was necessary in the transport industry. At present the recognized procedure was to pass on any increased costs resulting from labour demands to the manufacturer or the consumer.

The Minister of Transport had now refused to allow the British Transport Commission to continue with that easy method, presumably because the unions had agreed to cooperate in increasing efficiency when accepting the wage increase. The results obtained in the electricity supply industry had demonstrated that it was possible to offset rising costs by technical development, but it had to be acknowledged that technology played a predominant part in that industry.

The great merit of Mr Tooth's Paper had already been mentioned, but how much richer it would have been had he been able to say, as a port operator, what savings he had been able to make as a result of technical developments in ships, handling appliances, and buildings.

Undoubtedly the first step had to be a reduction in the quantity of labour employed and in that connexion Mr Wilson suggested that mechanization should not stop with handling, but should also include methods for reducing the number of staff required for tallying and for the making and sending out of accounts. On the latter point, was it worthwhile considering a uniform charge per ton of goods handled, with the object of reducing the number of checkers and clerks?

Admittedly the days had gone when, because of technical improvement, labour could

' R. K. Craig, "Passenger liner with engines aft". Trans Inst. Mar. Engrs, vol. 67, 1955, p. 439. 
be wantonly discharged, but with the present chronic employment position it should be possible to arrange for every improvement to be accompanied by some reduction in the amount of labour employed.

Mr Max Bentham (Consulting Engineer) regretted that Mr Shire had restricted his remarks on plant maintenance to what he termed "mobile cargo handling equipment".

The system outlined by Mr Shire was in keeping with experience and organizations used in large steel works for the same purpose.

Quay cranes were not included in the mobile plant covered. Whilst they were mobile plant it was realized that they differed from that described in that they could not be taken to the workshop; repairs and adjustments had to be made where they stood. It would be interesting to know if the Author had a similar system of inspection, short- and long-period overhauls, for those cranes. On the assumption that there were outworking gangs attending to the maintenance of quay cranes, did those men operate from the maintenance shop described in the Paper or from some other central works?

Ropes and chains featured so largely in dock handling equipment that the establishment of a department dealing with those items alone could be economical. The Author had mentioned that in well-established firms and large users of that type of equipment, such a department could be provided at a reasonable cost! Unless the regular inspection of wire ropes, slings, and chains were subcontracted to some competent organization, upon whom did the responsibility rest?

In a large Sheffield steelworks it had been found both economical and advisable for the firm to have their own department with comprehensive annealing and testing equipment, and to introduce a very tight system of identifying loose slings and chains, regular inspection, and recording of the maintenance of that equipment.

Could the Author indicate how effective control of those items was achieved in an area so widespread as most docks systems?

Mr Lees, in reply to Lt-Col. Edwards, said that the ship described in the Paper was not a Liberty ship (which was a cargo tramp) but a fast cargo liner, of which relatively few had been built in the United Kingdom towards the end of the 1939-45 war. Present British cargo-liner design was fundamentally similar to that shown in Fig. 1, Plates 1 and 2.

Turning to further points raised by Lt-Col. Edwards and by Mr Loewy and Mr Wilson, the Author's opinion regarding future design was contained in the last two paragraphs of the Paper.

Side openings might be quite valueless, say at a tidal dock (where, as at Southampton New Docks, the "rise and fall" might be $14 \mathrm{ft}$ ), and as for the basis ship, the difference between light and load draught was of the order of $20 \mathrm{ft}$. Cargo doors were not allowed below the waterline in Class I passenger ships.

Because of the requirement to fit transverse watertight bulkheads, it was not permissible in ocean-going ships to have undivided holds throughout the length of the ship and the siting of the main propelling machinery aft did not alter that.

In general cargo liners, the hatches were generally as long as they could be made without prejudice to other requirements; if owners considered that it was cheaper to install cranes longitudinally traversing such hatches, then such an arrangement would be adopted but the overall economy of such had yet to be proved except in certain specialized trades. If the hatches were made very wide, the hatch cover and supporting structure to carry the loading mentioned might require pillaring or might have to be of such dimensions and weight as would prove detrimental to the speedy working of proper stowage of the cargo; the longitudinal strength of the ship also had to be considered.

The naval architect's problem was to design a vessel which would enable cargo to be embarked, safely carried, and discharged with the utmost economy. How that was best accomplished would depend on many factors; it was agreed that one of them was a high ratio in terms of deadweight or cubic capacity to the actual weight of the vessel.

Mr Robinson had used the Author's figure, given in connexion with the strength of decks, to estimate requirements for storage space: the term "ton" was defined in numerous 
ways and it was safest to check the context-a "measurement" ton occupied $40 \mathrm{cu}$. $\mathrm{ft}$ of space.

Mr Matheson, in reply, said that Mr Jellett seemed to be under the impression that he had said a 30-ft column spacing was sufficient for all purposes. That, of course, was not so. He had tried to make it clear that he agreed there were quite a number of cases where a much wider spacing should be adopted. His purpose had been to point out that if one could not, on hard facts, justify a greater spacing then there was no need to nse it. He supposed that some of those present had seen the shed at Southampton, to which $\mathrm{Mr}$ Jellett had made reference, and in connexion with which a number of designs with different column spacings had been prepared. At the end of the day the widest spacing had been selected, and subsequently the shed had been greatly admired. But $\mathrm{Mr}$ Jellett had not stated the cost per cubic foot, and, after all, to a purely commercial concern that was really what counted. Unless it could be shown that extra revenue would result from extra expenditure then there was no justification for spending the money. At Southampton, of course, there was a prestige value in the case of the main passenger gateway to Britain.

The figure of 1 in 100 for maximum floor slope was considered desirable particularly where battery-operated trucks and other mechanical appliances were used, and also where high stacking was common practice. It was interesting to note that $\mathrm{Mr}$ Jellett had found no difficulty with slopes of 1 in 28 but such slopes should be avoided if at all passible in any new construction.

He agreed with Mr Robinson that there was a great need to reduce the time that goods remained in transit sheds. That was a very important point, because obviously the longer goods had to stay in shed, the greater the shed space required and the greater the cost involved to all concerned. That state of affairs often arose from poor shed clearance resulting from inadequate road and/or rail facilities for removing goods from port areas. Mr Robinson had also referred to the awkward shape of the sheds (Fig. 2, Plate 3). In fact, drawn to a larger scale, it would be seen that the "cut-off" at the ends of the sheds did not need to be as exaggerated as shown. Pallet stores and office and other accommodation could be incorporated in the awkward sections, leaving the more normal, and by far the larger, sections available for their proper purpose. The figure of 65 -ft quay width for the conditions mentioned in the Paper was given as the minimum and Mr Matheson was in general agreement with Mr Robinson's comments on that point.

Lt-Col. Edwards had referred to the advantages of the "dot-and-carry" type of quay crane. At present he was looking into the possibility of constructing a shed, on a very restricted site, to replace an existing single-storey building which had become inadequate for the needs of the trade using it. To give the necessary space the new shed would require to have ground and first-floor transit accommodation, open cargo storage on part of the roof, and the remainder of the roof occupied by offices and a car park. Road and rail facilities were required both in front and at the rear of the shed. Obviously every inch of space was important and the use of "dot-and-carry" cranes was almost unavoidable in that case. Fig. 38 illustrated the difficulties of meeting all the desirable but onerous requirements which had been called for.

The point raised by Lt-Col. Edwards that for export traffic it was desirable that road vehicles should be able to run into shed from the roadside, was, of course, an illustration of the need to balance one requirement against another in any dock layout and select what appeared to be the arrangement which would give the highest proportion of economical use. The arrangement in the cross-section (Fig. 2, Plate 3) would provide one answer to the difficulty in the case of two-storey sheds where the upper floor would be used for export cargo.

Mr Williams had very properly raised the matter of fire risk in sheds. Mr Matheson had purposely refrained from comment on that point, for it had been impossible to cover it within the limits of the Paper, particularly since the restrictions mentioned by Mr Williams were not applicable throughout all ports in the United Kingdom. The subject, indeed, was worthy of a separate Paper, and at present only one point could be made, namely, that the 
recommended step-back of any upper storey floor, provided, amongst other advantages, means of access between any sub-divisions of the shed.

With regard to Mr Ordman's remarks, it was true that the cost ratio of 1.6 to 1.8 between single- and double-storey sheds did not take into account the cost of extra land required in the case of a single-storey shed, but he had emphasized that the need to conserve space was one of the most vital factors in any layout. It would be difficult to assess, in many cases, what the cost of the additional land would be, and one could only base it on all known factors and decide whether to have a single-, double-, or multi-storey shed.
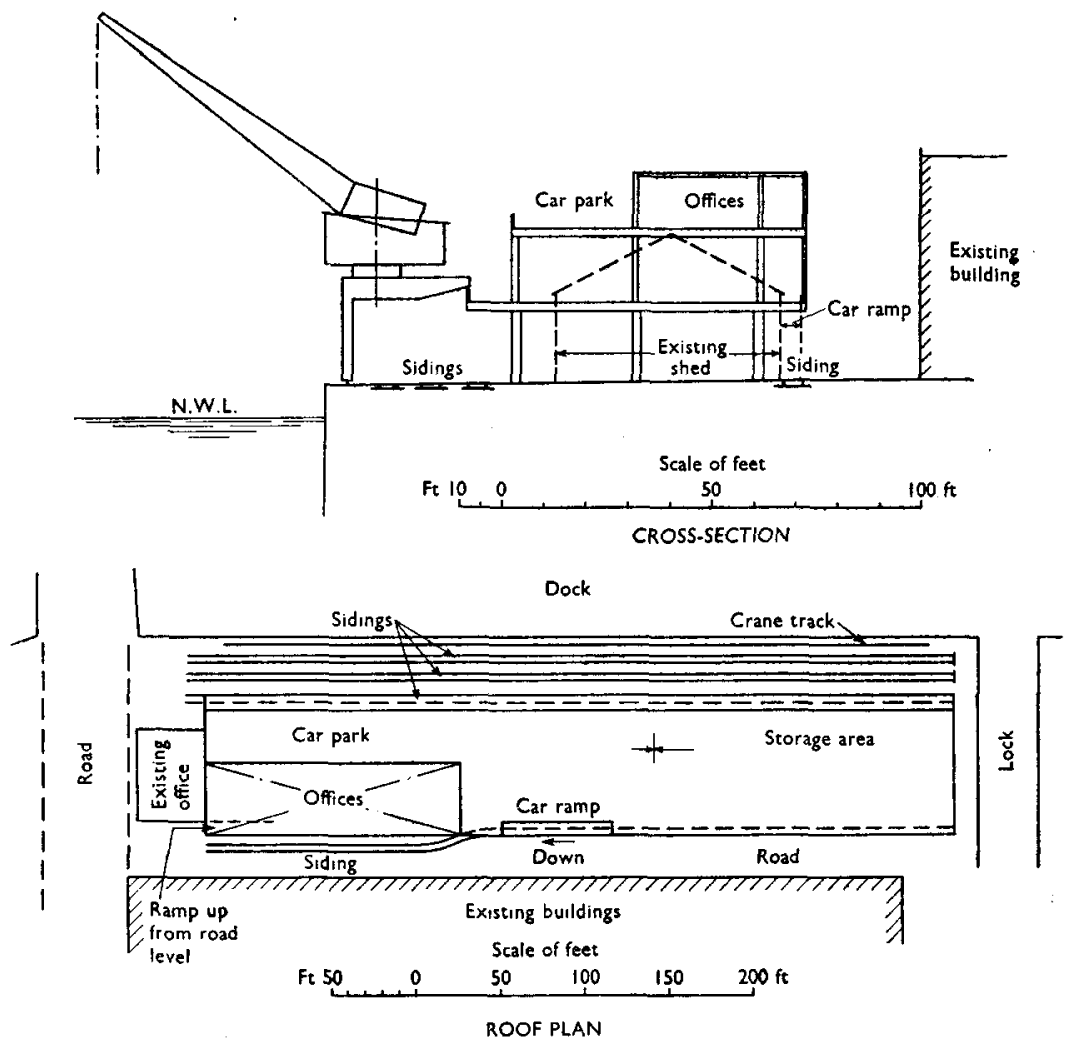

FIG. 38

Mr Sivewright had spoken about drivers preferring the positioning of cranes farther back from the quay edge. That was so, but he felt $\mathrm{Mr}$ Sivewright had perhaps based his comments on the fact that on one berth at Avonmouth the front legs of the cranes were only $2 \mathrm{ft} 6 \mathrm{in}$. from the quay edge. That was, unavoidably, too near, and the driving position in the cranes made it awkward for the drivers to obtain good visibility throughout normal operations. Mr Matheson had suggested a figure of $6 \mathrm{ft} 6 \mathrm{in}$. for ordinary conditions, and with a properly designed cab and controls there should be no objections to such a position. 
Mr Shire, in reply, agreed that Mr Gamble's cranes were excellent, but Mr Gamble was doing a specialized job, he had very special drivers, and he could therefore afford to buy what was only a "Rolls Royce" crane. He did not think that the Port of London Authority's limited and intermittent bulk-handling requirements warranted such an expenditure.

With regard to the hours between overhauls, he agreed that the figures were very conservative, and since the Paper had been written the times had been extended, but, owing to the high incidence of damager, more men had been found to be necessary.

Mr Hammersley had asked about the mobile crane for timber handling. It was basically a standard crane with a special jib; the safe working load was 1 ton at maximum outreach, increasing in the normal manner as the radius decreased, without any special derating.

Diesel-electric conversion of steam cranes had not been examined for the cost was considered to be too great.

The roof transporter was moved from one loophole to the next from the roof; in many instances push buttons at each position would be an advantage, but in the case mentioned the additional expenditure could not be warranted.

The tubular steel handtruck was the first development to meet the Authority's requirements, and improvements would undoubtedly be forthcoming.

Regarding mobile plant inspectors visiting working areas, he did not think that special men were generally necessary in the docks, for the normal supervisor could quickly reach any point when required.

Mr Pannell had asked about flame descaling. Mr Shire's experience was that the method was costly and frequently unsatisfactory; in certain circumstances it involved an unacceptable fire risk.

$\mathrm{Mr}$ Sivewright asked if pallet repair costs could be related to tonnage handled or the number of lifts. Unfortunately that valuable information was not available. Most repairs were necessitated by damage which appeared to be an inherent factor in the pieceworking system.

With regard to gravity chutes, his experience had been that when fitted they were rarely used, for they were unsatisfactory for handling general cargo.

The reason for the Authority's predominance of d.c. cranes was the lack of a.c. Some a.c. cranes were now being built, and he anticipated that they would be equally, if not more, satisfactory than the d.c.

Mr McBride had asked about wire rope examinations. They were carried out by a separate body of men, irrespective of the type of plant or location, and in general conformed to statutory requirements. Adequate records were maintained, and they were being improved by the introduction of proprietary mechanized systems.

Anti-freeze was used in winter in engine cooling systems, but precautions were taken to prevent pilferage.

The time given for oiling and greasing referred to one crane. The work was undertaken before and after normal working hours, during dock labour's meal breaks, and as and when the plant was not at work for short periods. In London the drivers were not generally kept to one crane, nor did they do any maintenance work.

With regard to tubular jibs, Mr Shire's experience was limited, but no repair difficulties had yet been encountered. He thought that the average welder or boiler maker would readily acquire the technique of working on tubular structures.

Mr Bentham asked about quay-crane maintenance. That work was undertaken by outworking gangs and by the heavy repair shops. The mobile plant was generally treated as a separate requirement.

The control of inspection, annealing, testing, etc., of lifting gear was made effective by an adequate system of records, and by having responsible men in charge of the work, and of the stores in which the gear was kept.

$\mathbf{M r}$ Tooth, in reply, said that from the operating point of view there was a very real link between the various questions asked. Such matters had been raised as the size and type of ships, the design of transit sheds, the size of sheds, the size of doors, the need for 
loading platforms, whether there should be gravity chutes, how sheds were going to be used, why the ship always beat the quay (if it did!), whether there should be good access to the shed for mechanical equipment and transport, the economic aspeets of mechanization, port layout, and even why coal grabs should be used for sugar which had not yet been refined!

It was well known that there were important developments in palletization in many industries. British Railways were now carrying over 200,000 tons of palletized goods every year and industrial premises were being built, so planned that the dimensions of the sections were multiples of the sizes of the unit loads which the particular organizations normally handled. That was happening not only in the United Kingdom but abroad, and in some countries on the Continent other interesting things were occurring. The Swiss Federal Railways, for instance, owned a large number of 32 -in. $\times 48$-in. pallets (he thought about 180,000 ) and, with 600 industrial concerns in and around Switzerland, had organized a pallet pool. The arrangement was that if a member organization were going to send, for example, 40 tons of goods on 70 pallets, it delivered its 70 pallet loads to the Swiss Railway depot and received 70 similar pallets in exchange. When the loads ultimately left the custody of the Swiss Railways the receiver, also a member of the organization, also gave 70 pallets in exchange.

He mentioned that to show that palletization was no longer an idea, it was something real. Moreover, palletized traffic was not only a land development, it was seeping into the short sea trade routes and there was no doubt whatever that sooner or later it would seep into trans-ocean routes. Such a development could not occur without raising many fundamental questions in the port industry.

The potentialities of the machine were obviously much too important for dock authorities to overlook. They were using the fork-lift truck with a pallet of their own ownership for the time being, but it did not follow that that method would be the one for the future. If palletized cargo became common, port handling methods might be much simplified and the need for a dock-tool pallet would diminish. Certainly transit shed design and the layout of premises generally would be affected; undoubtedly in the future-in 20 or 30 years' time, perhaps-ship design would alter too. In the meantime, however, the policy in London was to introduce mechanical handling methods where possible, employing the dock-tool pallet where suitable.

Correspondence will be published in a later number of the Proceedings.-SEC. 